\title{
Correction to: The role of diaphragmatic ultrasound as a predictor of successful extubation from mechanical ventilation in respiratory intensive care unit
}

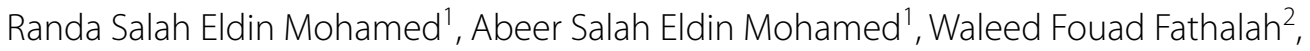 \\ Mohamed Farouk Mohamed ${ }^{1}$ and Ahmed Aelgharib Ahmed ${ }^{3 *}$
}

Correction to: Egypt J Bronchol15, 51 (2021)

https://doi.org/10.1186/s43168-021-00095-6

After publication of the original article [1], the authors identified an error in the author name of Abeer Salah Eldin Mohamed.

The incorrect author name is: Abeer Salah Eldin Mahmoud

The correct author name is: Abeer Salah Eldin Mohamed

The author group has been updated above and the original article [1] has been corrected.

\section{Author details}

${ }^{1}$ Department of Pulmonology, Beni Suef University Faculty of Medicine, Beni Suef, Egypt. ${ }^{2}$ Department of Endemic Medicine and Hepatology, Cairo University Kasr Alainy Faculty of Medicine, Cairo, Egypt. ${ }^{3}$ National Institute of Chest Hospital, 2 street Talat harb, Giza, Egypt.

Published online: 14 December 2021

\footnotetext{
Reference

1. Mohamed RS et al (2021) The role of diaphragmatic ultrasound as a pre-

dictor of successful extubation from mechanical ventilation in respiratory
}

The original article can be found online at https://doi.org/10.1186/s43168021-00095-6.

${ }^{*}$ Correspondence: dr.ahmed101@yahoo.com

${ }^{3}$ National Institute of Chest Hospital, 2 street Talat harb, Giza, Egypt

Full list of author information is available at the end of the article intensive care unit. Egypt J Bronchol 15:51. https://doi.org/10.1186/ s43168-021-00095-6

\section{Springer Open}

(0) The Author(s) 2021. Open Access This article is licensed under a Creative Commons Attribution 4.0 International License, which permits use, sharing, adaptation, distribution and reproduction in any medium or format, as long as you give appropriate credit to the original author(s) and the source, provide a link to the Creative Commons licence, and indicate if changes were made. The images or other third party material in this article are included in the article's Creative Commons licence, unless indicated otherwise in a credit line to the material. If material is not included in the article's Creative Commons licence and your intended use is not permitted by statutory regulation or exceeds the permitted use, you will need to obtain permission directly from the copyright holder. To view a copy of this licence, visit http://creativecommons.org/licenses/by/4.0/. The Creative Commons Public Domain Dedication waiver (http://creativeco mmons.org/publicdomain/zero/1.0/) applies to the data made available in this article, unless otherwise stated in a credit line to the data. 